\title{
Diagnostic accuracy of dual-source coronary computed tomography angiography in patients after bypass grafting
}

Trafność diagnostyczna dwuźródłowej tomografii komputerowej w ocenie pacjentów po przebytej operacji pomostowania aortalno-wieńcowego

\section{Cezary Kępka, Maksymilian Opolski, Mariusz Kruk, Jerzy Pręgowski, Anna Kowalewska, Paulina Wilkowska, Zofia Dzielińska, Maciej Karcz, Witold Rużyłło, Marcin Demkow}

Institute of Cardiology, Warsaw, Poland

\begin{abstract}
Aim: To determine the diagnostic accuracy of dual-source (DS) coronary computed tomography angiography (CCTA) with improved temporal resolution in a population of symptomatic patients after coronary artery bypass grafting (CABG) compared to invasive coronary angiography (ICA).

Material and methods: Ninety (74 male, mean age: $68 \pm 9$ years) symptomatic post-CABG patients from the prospective ANIN Coronary Computed Tomography Angiography Registry who underwent both DS-CCTA and ICA for suspected graft disease were included in the analysis. A total of 202 grafts (67 arterial grafts, 135 venous grafts) and 1,105 segments in 360 native coronary arteries $\geq 1.5 \mathrm{~mm}$ in diameter were evaluated for the presence of significant stenosis, defined as $\geq 50 \%$ decrease in vessel diameter. Results were compared with ICA as the standard of reference.

Results: Sensitivity, specificity, and positive and negative predictive values of DS-CCTA for the detection of significant lesions in bypass grafts were $99 \%, 96 \%, 94 \%$, and $99 \%$, respectively. Segment-by-segment analysis of native coronary arteries for the detection of obstructive disease yielded sensitivity of $91 \%$ with specificity of $92 \%$. If analysis was restricted to non-grafted and distal runoff segments, sensitivity and specificity were $88 \%$ and $96 \%$, respectively. The presence of coronary calcium deposits was associated with a significant decrease in diagnostic accuracy of DS-CCTA.

Conclusions: The DS-CCTA allows reliable evaluation of suspected graft disease in symptomatic post-CABG patients, whereas ICA is still required for the assessment of significant stenoses in native coronary circulation.
\end{abstract}

Key words: dual-source coronary computed tomography angiography, coronary artery bypass grafts, coronary artery disease

\section{Streszczenie}

Cel: Ocena przydatności diagnostycznej dwuźródłowej tomografii komputerowej u pacjentów z objawami po wcześniejszym pomostowaniu aortalno-wieńcowym w porównaniu z koronarografią klasyczną.

Materiał i metodyka: Analizie poddano 90 pacjentów z objawami (74 mężczyzn, średni wiek: $68 \pm 9$ lat) z prospektywnego rejestru (AninCTA Registry), u których wykonano badanie dwuźródłowej tomografii komputerowej oraz koronarografii inwazyjnej. Analizowano 202 pomosty (67 tętniczych oraz 135 żylnych) oraz 1105 segmentów w 360 natywnych tętnicach wieńcowych o średnicy powyżej 1,5 mm i oceniano obecność istotnego zwężenia (> 50\%). Wyniki porównano z rezultatami badania koronarograficznego, które traktowano jako metodę referencyjną.

Wyniki: Czułość, swoistość, pozytywna i negatywna wartość predykcyjna tomografii komputerowej w identyfikacji istotnych zwężeń w pomostach wyniosły odpowiednio: 99\%, 96\%, 94\% i 99\%. W analizie segmentów natywnych tętnic wieńcowych czułość i swoistość kształtowały się na poziomie odpowiednio 91\% i 92\%. Analiza naczyń, do których nie doszyto pomostów, oraz natywnych segmentów poniżej zespoleń wykazała czułość i swoistość wynoszące odpowiednio 88\% i 96\%. Obecność zwapnień spowodowała istotne zmniejszenie przydatności klinicznej.

Wnioski: Dwuźródłowa tomografia komputerowa jest przydatną klinicznie metodą oceny pomostów aortalno-wieńcowych u pacjentów z objawami, jednak do oceny natywnych tętnic wieńcowych często wymagana jest koronarografia inwazyjna.

Słowa kluczowe: dwuźródłowa tomografia komputerowa, pomostowanie aortalno-wieńcowe, choroba wieńcowa

Corresponding author/Adres do korespondencji:

Cezary Kępka MD, PhD, Institute of Cardiology, 42 Alpejska, 04-628 Warsaw, Poland, tel.: +48 22343 42 72, e-mail: ckepka@ikard.pl

Praca wpłynęła: 21.06.2012, przyjęta do druku: 6.08.2012. 


\section{Introduction}

Recurrence of angina is a common problem in the follow-up of patients after coronary artery bypass grafting (CABG) [1]. Although early symptoms are mostly caused by an acute graft failure, anginal complaints later after surgery may be the result of progression of obstructive disease, either in the native coronary circulation or in the bypass conduits [1, 2]. Thus, a comprehensive imaging modality for the evaluation of symptomatic post-CABG patients should include both bypass grafts and native coronary arteries.

Although invasive coronary angiography (ICA) is the reference method for detection of bypass graft disease, it is a time-consuming procedure that carries potential risk of catheter-related complications, large contrast use and increased radiation exposure [3]. Rapid advances in multidetector coronary computed tomography angiography (CCTA) have facilitated noninvasive visualization of coronary arteries [4]. Results of studies using 64-detector CCTA have shown good and unsatisfactory accuracy for the detection of obstructive disease in bypass grafts and native coronary circulation, respectively [5-12]. Thus, performance of CCTA for evaluation of graft patency in symptomatic post-CABG patients is considered an appropriate indication, whereas assessment of native coronary arteries after CABG is not indicated in the CCTA appropriateness criteria [13].

Recently, a newer dual-source (DS) CT scanner has been introduced that offers the potential for improved temporal resolution of $83 \mathrm{~ms}$ [14]. Until now, only a few studies have evaluated the diagnostic accuracy of DS-CCTA after CABG $[15,16]$.

\section{Aim}

In this study, we assessed the accuracy of DS-CCTA for the identification of significant disease both in the bypass grafts and native coronary arteries in a relatively large number of symptomatic patients after CABG. Results were compared to ICA.

\section{Material and methods}

\section{Study design and population}

The study was designed as a blinded, cross-sectional assessment comparing DS-CCTA with ICA for identification of significant coronary and graft stenosis. During the period from March 2008 to December 2011, a total of 90 consecutive symptomatic post-CABG patients (74 male, mean age $68 \pm 9$ years) from the prospective ANIN Coronary Computed Tomography Angiography Registry underwent both DS-CCTA and ICA because of suspected graft or coronary artery disease. ICA was performed within 4 weeks of DSCCTA in all patients. Patients with contraindications for administration of contrast media, renal insufficiency (serum creatinine $>1.5 \mathrm{mg} / \mathrm{dl}$ ), atrial fibrillation, and inability to comply with breath-hold commands were excluded. The study was approved by the institutional ethics committee, and all participants gave informed written consent.

\section{Coronary computed tomography angiography data acquisition and image reconstruction}

All scans were performed using a DS computed tomographic scanner (Somatom Definition, Siemens Healthcare, Forchheim, Germany) during a single breath hold. All CCTA studies were conducted after sublingual administration of nitroglycerine $(0.8 \mathrm{mg})$, provided the systolic blood pressure was above $90 \mathrm{~mm} \mathrm{Hg}$. In addition, intravenous metoprolol (sequential doses of $2.5 \mathrm{mg}$, maximal dose $10 \mathrm{mg}$ ) was administered in patients with a heart rate over 65 beats/min immediately before CCTA. The CCTA scan parameters were as follows: rotation time $330 \mathrm{~ms}$, collimation $0.6 \mathrm{~mm}$, and tube voltage of $100-140 \mathrm{kV}$ adjusted manually for body mass index. All scans were performed using an electrocardiogram-gated retrospective acquisition protocol. For acquisition of the volume data set, a bolus of iodinated contrast material (Iomeron 400, Bracco Altana Pharma, Konstanz, Germany) was administered through an antecubital vein at a rate of $6 \mathrm{ml} / \mathrm{s}$. The contrast volume ranging from $80 \mathrm{ml}$ to $120 \mathrm{ml}$ was adjusted to the scan duration (pitch and scan range dependent). The pitch varied between 0.2 and 0.3 and was automatically adapted to the heart rate. The temporal resolution was $83 \mathrm{~ms}$. The scanning range included the entire course of all venous and arterial grafts, including the most proximal part of the internal mammary artery grafts at their subclavian origin.

Scan data were reconstructed routinely in mid-to-end systole and diastole (35\% to $45 \%$ and $65 \%$ to $75 \%$ of the R-R interval, respectively). Data sets containing unsatisfactory motion quality were individually optimized by changing the reconstruction window. Images were reconstructed with a slice thickness of $0.6 \mathrm{~mm}$, and reconstruction increment of $0.4 \mathrm{~mm}$, using a medium-to-smooth convolution kernel (B26f). In the presence of vascular clips, massive calcification or stents a sharp kernel (B46f) was applied to compensate the blooming artefacts. Using a method proposed by the European Working Group for Guidelines on Quality Criteria in CT [17], the average estimated effective radiation dose was $18 \pm 6.4 \mathrm{mSv}$.

\section{Coronary computed tomography angiography data analysis}

All reconstructed images were evaluated offline using a dedicated workstation (Leonardo Workstation, Siemens, Erlangen, Germany). One experienced cardiologist who was aware of the surgical report but blinded to angiographic findings analyzed all bypass grafts and native coronary arteries with the use of thin-slab maximum intensity projections, curved multiplanar reconstructions, and threedimensional volume-rendered reconstructions. In addition, 
$50 \%$ of cases were evaluated by 2 independent observers to assess inter-observer variability. All bypass grafts (body and proximal and distal anastomotic sites) and coronary arteries were visually evaluated for the presence of occlusions, and significant stenoses defined as a lumen reduction of at least $50 \%$ to $99 \%$. In case of a jump graft ( $\geq 2$ anastomoses per graft), all graft segments between the proximal anastomoses and each coronary insertion were analyzed separately [15]. Native coronary arteries were evaluated according to the 16-segment modified American Heart Association classification [18], and divided into grafted and non-grafted coronary segments. The grafted segments included all segments located proximally and at the level of graft insertion. The distal runoffs were defined as coronary segments located distal to the segment at which the graft was inserted. According to image quality, each coronary or graft segment was first described as interpretable or not, then evaluable segments were visually classified as good (absence of any artefacts related to motion, low signal-to-noise ratio, calcium deposits, and/or vascular clips), moderate (presence of artefacts but evaluation possible with moderate confidence), or poor (presence of significant artefacts and evaluation possible with low confidence). Segmental coronary calcification was ranked as absent, moderate (isolated calcium spots and calcium covering $<50 \%$ of lumen in cross-section), or severe (extensive calcification and calcium covering $\geq 50 \%$ of lumen in cross-section) as previously described [12]. Coronary arteries or grafts with stents were not excluded from the analysis.

\section{Invasive coronary angiography}

Invasive coronary angiography was performed using a standard angiography system (Axiom Artis, Siemens, Germany) and served as the gold-standard reference for comparison with DS-CCTA. All standard orthogonal views for native coronary arteries and at least 2 orthogonal views for each bypass graft were obtained. Angiograms were evaluated by a single experienced cardiologist who was blinded to DS-CCTA findings. Lesions with a lumen reduction of $\geq 50 \%$ by visual assessment (both in native coronary vessels and graft conduits) were considered to represent significant stenoses. Only grafts and coronary segments with a diameter $\geq 1.5 \mathrm{~mm}$ were analyzed.

\section{Statistical analysis}

Continuous data were reported as mean $\pm \mathrm{SD}$, and categorical variables were expressed as frequencies and percentages. The diagnostic accuracy of DS-CCTA for the detection of significant stenoses in comparison to ICA was expressed as sensitivity, specificity, positive predictive value (PPV), and negative predictive value (NPV) with corresponding 95\% confidence intervals. In addition, positive and negative likelihood ratios were calculated. Analyses were performed on a (1) per-vessel basis evaluating the presence of significant stenoses in a given bypass graft and in each major coronary artery (left main, left anterior descending coronary artery, left circumflex, and right coronary artery), (2) per-segment basis comparing each segment in every native coronary artery, and (3) per-patient basis assessing the presence of any significant stenosis in bypass grafts, in a combination of non-grafted arteries and distal runoff vessels, and in a combination of bypass grafts, non-grafted arteries and distal runoff vessels in a given patient. In the per-segment analyses, segments and vessels classified as unevaluable were excluded. In the perpatient analyses, patients with a detectable stenosis in the bypass grafts or the native coronary arteries, as well as patients with at least 1 unevaluable coronary segment, were classified as "positive" (because the presence of a stenosis could not be ruled out by DS-CCTA and ICA would be necessary). The differences in diagnostic accuracy were tested for significance by using a $\chi^{2}$ test. When appropriate, Mantel-Haenszel $\chi^{2}$ statistics was used in ordinal group comparisons. Inter-observer variability for the detection of significant stenoses was determined by Cohen's $\kappa$ coefficient. Calculations were performed by the VassarStats website for statistical computation (http://faculty.vassar.edu/lowry/VassarStats.html).

\section{Results}

Patient characteristics and scan demographics are listed in Table 1. The mean interval between CABG and CCTA was $8.3 \pm 6.4$ (range: 0 -24) years. The mean body mass index was $28.1 \pm 4.1 \mathrm{~kg} / \mathrm{m}^{2}$, and the mean heart rate during CT scan was $64 \pm 7$ beats/min. No patient was excluded from the analysis because of a technically inadequate CCTA scan.

\section{Bypass grafts}

A total of 202 bypass grafts, including 67 arterial and 135 venous grafts, were evaluable both in ICA and DS-CCTA. Overall, all 202 bypass grafts demonstrated sufficient image quality for the assessment of obstructive disease by DSCCTA. According to ICA, 127 (63\%) bypass grafts were patent and non-stenotic, while the remaining 75 (37\%) presented with either complete occlusion (44 grafts, $22 \%$ ) or significant stenosis (31 grafts, 15\%). Forty-two of 44 (95\%) occlusions and 30 of 31 (97\%) graft stenoses were correctly recognized by DS-CCTA (Figure 1). We identified 2 totally occluded grafts with Thrombolysis In Myocardial Infarction flow grade 1 that were classified as significant stenoses using DS-CCTA. Additionally, one very short membranouslike stenosis located at the distal anastomotic site in a venous graft to the first obtuse marginal branch was missed by DS-CCTA. Of the patent and non-stenotic grafts, 122 of 127 (96\%) stenoses were correctly ruled out in DSCCTA (Figure 2), whereas in 5 cases false-positive findings were observed. All of the 5 false-positive lesions were located in venous grafts, of which 3 were placed at the proximal 
Table 1. Patient characteristics and scan demographics $(n=90)$

Tabela 1. Charakterystyka kliniczna pacjentów oraz dane zwiazane z badaniem tomografii komputerowej $(n=90)$

\begin{tabular}{|c|c|}
\hline Age [years] & $68 \pm 9$ \\
\hline Male & $74(82 \%)$ \\
\hline Body mass index $\left[\mathrm{kg} / \mathrm{m}^{2}\right]$ & $28.1 \pm 4.1$ \\
\hline Interval from CABG to DS-CCTA [years] & $8.3 \pm 6.4$ \\
\hline Diabetes mellitus & $28(31 \%)$ \\
\hline Hypertension* & $72(80 \%)$ \\
\hline Hyperlipidemia\& & $76(84 \%)$ \\
\hline Current smoker & $15(17 \%)$ \\
\hline Previous myocardial infarction & $54(60 \%)$ \\
\hline Previous coronary stenting & $31(34 \%)$ \\
\hline \multicolumn{2}{|l|}{ Type of bypass graft } \\
\hline Left or right internal mammary artery & $61(30 \%)$ \\
\hline Radial artery & $6(3 \%)$ \\
\hline Saphenous vein graft & $135(67 \%)$ \\
\hline \multicolumn{2}{|l|}{ DS-CCTA examination } \\
\hline Heart rate during scanning [beats/min] & $64 \pm 7$ \\
\hline Pitch & $0.27 \pm 0.04$ \\
\hline Scan time $[s]$ & $14.6 \pm 2.9$ \\
\hline Scan length $[\mathrm{cm}]$ & $20.9 \pm 3.4$ \\
\hline Contrast volume [ml] & $103 \pm 14$ \\
\hline $\mathrm{DLP}[\mathrm{mGy} \times \mathrm{cm}]$ & $1286 \pm 458$ \\
\hline Effective dose [mSv] & $18 \pm 6.4$ \\
\hline \multicolumn{2}{|c|}{$\begin{array}{l}\text { Data are presented as the number of patients (percentage) or as mean } \\
\pm S D \text {. } \\
\text { *Use of antihypertensive drugs and/or blood pressure } \geq 140 / 90 \mathrm{~mm} \mathrm{Hg} \\
\text { \&Use of lipid-lowering drugs and/or total serum cholesterol } \geq 200 \mathrm{~mm} \mathrm{Hg} \\
C A B G \text { - coronary artery bypass grafting, DS-CCTA - dual-source coro- } \\
\text { nary computed tomography angiography, DLP-dose length product }\end{array}$} \\
\hline
\end{tabular}

third of bypass grafts to the intermediate branch, first diagonal branch, and second obtuse marginal branch. The remaining 2 false-positive stenoses were identified in the midportion and at the distal anastomotic site of venous grafts to the first obtuse marginal branch, and second diagonal branch, respectively. Thus, for the detection of significant graft disease (stenosis or occlusion), a sensitivity of $99 \%$ (74/75), specificity of $96 \%$ (122/127), PPV of $94 \%(74 / 79)$, and NPV of 99\% (122/123) were observed (Table 2). The diagnostic accuracy of DS-CCTA for the detection of significant stenosis was excellent $(100 \%)$ in arterial grafts and tended to be higher compared to venous grafts (100\% vs. $96 \%, p=0.08)$. Agreement between observers for the detection of significant arterial and venous graft disease was good ( $\kappa$ values of 0.93 and 0.86 , respectively).

\section{Native coronary arteries}

Of a total of 1440 coronary segments in 90 patients, 183 segments distal to 132 complete vessel occlusions, and
134 segments with a diameter $<1.5 \mathrm{~mm}$ on ICA were excluded from analysis. Thus, potentially 1,123 assessable coronary segments remained in the analysis. Of these 1,123 segments, 18 segments (2\%) were classified as unevaluable by DS-CCTA due to presence of motion artefacts in 11 cases and severe calcifications in 7 cases. The final statistical analysis was thus performed on 1,105 comparable segments. On the basis of ICA, 714 (65\%) segments were free of stenosis, while the remaining 391 (35\%) segments presented with significant obstructive disease. By DS-CCCTA, image quality was classified as either good, moderate or poor in 52\%, 39\% and 9\% of segments, respectively. Of the non-stenotic coronary segments, 656 of 714 (92\%) stenoses were correctly ruled out by DS-CCTA, whereas in 58 cases false-positive findings were seen. The presence of significant stenosis was correctly recognized in 356 of 391 (91\%) segments, while 35 lesions were underestimated using DS-CCTA. Thus, for the detection of significant coronary disease (stenosis or occlusion) in evaluable segments, a sensitivity of $91 \%$ (356/391), specificity of $92 \%$ (656/714), PPV of $86 \%$ (356/414), and NPV of $95 \%$ $(656 / 691)$ were observed (Table 2$)$. When unevaluable segments were classified as positive, overall diagnostic accuracy decreased from 92\% (1012/1105) to 91\% (1021/1123) because ICA demonstrated significant stenoses in 9 of 18 unevaluable segments.

If analysis was restricted to non-grafted and distal runoff segments, a total of 796 coronary segments were available for analysis. By DS-CCTA, 8 of 796 segments (1\%) were unevaluable because of motion artefacts and severe calcifications in 6 and 2 cases, respectively. In the 788 evaluable segments, ICA demonstrated a significant stenosis in $166(21 \%)$ segments and absence of stenosis in 622 (79\%) segments. On the basis of DS-CCTA findings, 146 of $166(88 \%)$ significant lesions were identified (Figure 3), and 597 of 622 (96\%) stenoses were correctly ruled out. Thus, for the detection of significant coronary artery disease in evaluable non-grafted and runoff segments, a sensitivity of $88 \%$ (146/166), specificity of $96 \%$ (597/622), PPV of $85 \%$ (146/171), and NPV of $97 \%$ (597/617) were observed (Table 2). Agreement between observers for the evaluation of significant disease in native coronary segments ( $\kappa$ value 0.77 ) and distal runoff segments ( $\kappa$ value 0.95 ) was acceptable.

Influence of coronary calcium on the diagnostic accuracy of dual-source coronary computed tomography angiography

We investigated the effect of coronary calcium load on the diagnostic performance of DS-CCTA for the detection of significant coronary artery disease in a segmentbased analysis. Absent, moderate, and severe calcifications were observed in 388 (35\%), 496 (45\%), and 221 (20\%) coronary segments, respectively. The diagnostic accuracy of DS-CCTA in non-calcified coronary segments 

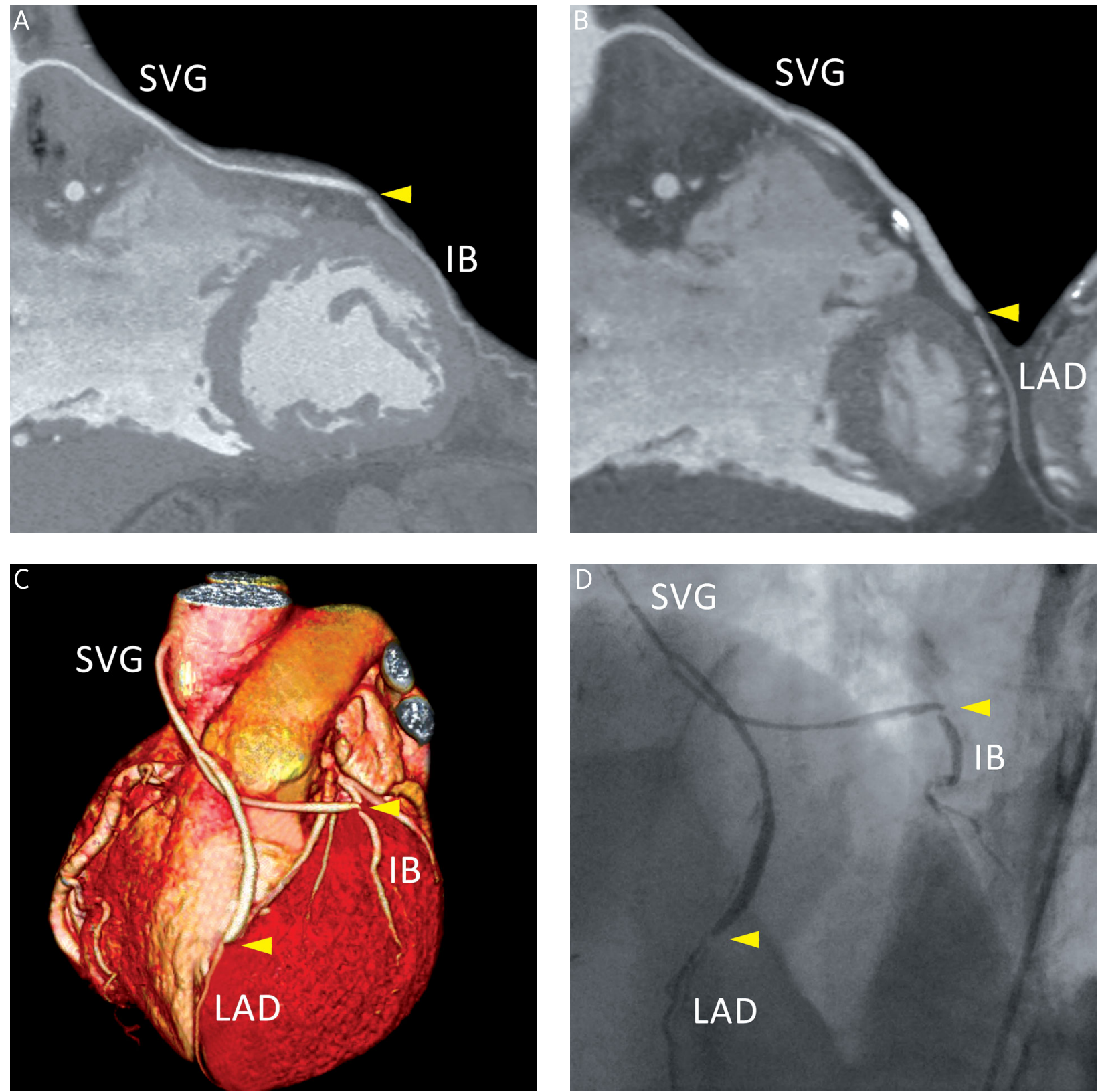

Fig. 1. Curved multiplanar reconstructions of tight stenoses at the anastomotic sites (yellow arrowheads) of the venous jump graft to the left anterior descending coronary artery and the intermediate branch (A, B). Three-dimensional volume-rendered reconstruction of stenotic lesions at the anastomotic sites (yellow arrowheads) of the venous graft (C). Corresponding invasive angiogram confirms dual-source coronary computed tomography angiography findings (D)

$I B$ - intermediate branch, LAD - left anterior descending coronary artery, SVG - saphenous vein graft

Ryc. 1. Badanie tomografii komputerowej. Rekonstrukcja wielopłaszczyznowa pokazująca ciasne (żółte strzałki) zwężenia w miejscach zespolenia pomostu żylnego z gatęzią przednią zstępującą oraz gatęzią pośrednią $(A, B)$. Rekonstrukcja objętościowa przedstawiająca oba istotnie zwężone zespolenia (żółte strzałki) (C). Obraz inwazyjnej koronarografii potwierdzający diagnozę postawiona na podstawie badania metodą tomografii komputerowej (D) IB - gałąź pośrednia, LAD - gatą́ przednia zstępująca, SVG - pomost żylny

was higher compared to moderate (95\% vs. $92 \%, p=$ $0.066)$ and severe ( $95 \%$ vs. $85 \%, p<0.001)$ coronary calcification. In a subgroup of non-grafted and distal runoff segments, DS-CCTA was highly accurate in the absence of coronary calcification (accuracy 97\%); however, moderate and severe calcification reduced accuracy to $93 \%$ 

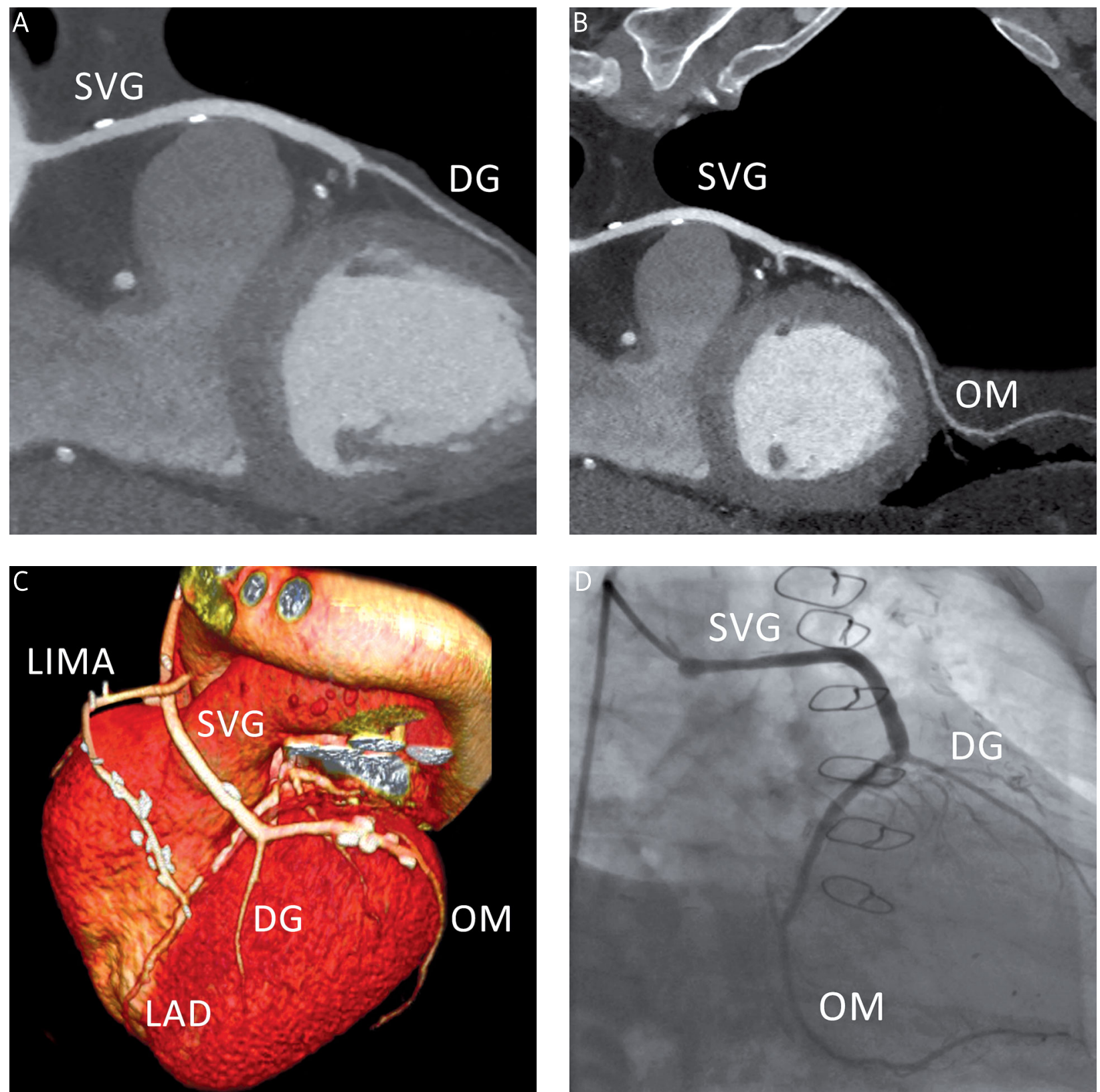

Fig. 2. Curved multiplanar reconstructions of the patent and non-stenotic venous jump graft to the first diagonal branch and second obtuse marginal branch (A, B). Three-dimensional volume-rendered reconstruction visualizes normal venous jump graft and left internal mammary artery graft (C). Corresponding invasive angiogram confirms dual-source coronary computed tomography angiography findings (D)

$D G$ - diagonal branch, $L A D$ - left anterior descending coronary artery, LIMA - left internal mammary artery graft, OM - obtuse marginal branch, SVG - saphenous vein graft

Ryc. 2. Badanie metodą tomografii komputerowej. Rekonstrukcja wielopłaszczyznowa pokazująca prawidłowo funkcjonujący skaczący pomost żylny do pierwszej gatęzi diagonalnej oraz gatęzi brzeżnej (A, B). Rekonstrukcja objętościowa przedstawiająca pomost żylny oraz zespolenia (C). Obraz inwazyjnej koronarografii potwierdzajacy diagnozę postawiona na podstawie badania metodą tomografii komputerowej (D)

DG - gałąź diagonalna, LAD - gałąź przednia zstępująca, LIMA - lewa tętnica piersiowa wewnętrzna, OM - gałąź brzeżna, SVG - pomost żylny

and $89 \%$, respectively. The effect of coronary calcification on the diagnostic accuracy of DS-CCTA is summarized in Table 3.
Per-patient graft or coronary artery disease

In the per-patient analysis assessing the presence of any significant graft disease, 53 of 54 (98\%) patients 
Table 2. Diagnostic accuracy of DS-CCTA for the stection of significant graft and coronary artery disease

Tabela 2. Przydatność diagnostyczna dwuźródłowej tomografii komputerowej w diagnostyce istotnych zwężeń w pomostach aortalno-wieńcowych oraz $w$ natywnych tętnicach wieńcowych

\begin{tabular}{|c|c|c|c|c|c|c|c|c|c|c|c|c|}
\hline & $\begin{array}{c}\text { Prevalence } \\
\text { of disease [\%] }\end{array}$ & $N$ & TP & $\mathrm{TN}$ & FP & $\mathrm{FN}$ & $\begin{array}{c}\text { Sensivity } \\
{[\%]}\end{array}$ & $\begin{array}{c}\text { Specificity } \\
{[\%]}\end{array}$ & $\begin{array}{l}\text { PPV } \\
{[\%]}\end{array}$ & $\begin{array}{l}\text { NPV } \\
{[\%]}\end{array}$ & $\mathrm{LR}+$ & LR- \\
\hline All grafts & 37 & 202 & 74 & 122 & 5 & 1 & $99(92-100)$ & $96(91-98)$ & $94(85-98)$ & $99(95-100)$ & 25.1 & 0.01 \\
\hline Arterial grafts & 24 & 67 & 16 & 51 & 0 & 0 & $100(76-100)$ & $100(91-100)$ & $100(76-100)$ & $100(91-100)$ & $\infty$ & 0 \\
\hline Venous grafts & 44 & 135 & 58 & 71 & 5 & 1 & 98 (90-100) & $93(85-97)$ & $92(82-97)$ & 99 (91-100) & 14.9 & 0.02 \\
\hline $\begin{array}{l}\text { All coronary } \\
\text { segments }\end{array}$ & 35 & 1105 & 356 & 656 & 58 & 35 & 91 (88-94) & $92(90-94)$ & $86(82-89)$ & 95 (93-96) & 11.2 & 0.10 \\
\hline $\begin{array}{l}\text { Nongrafted } \\
\text { and runoffs }\end{array}$ & 21 & 788 & 146 & 597 & 25 & 20 & $88(82-92)$ & $96(94-97)$ & 85 (79-90) & $97(95-98)$ & 21.9 & 0.12 \\
\hline Runoffs & 6 & 154 & 9 & 140 & 4 & 1 & $90(54-99)$ & 97 (93-99) & $69(39-90)$ & $99(95-100)$ & 32.4 & 0.10 \\
\hline Coronary vessels & 68 & 360 & 240 & 100 & 14 & 6 & 98 (94-99) & $88(80-93)$ & 94 (91-97) & $94(88-98)$ & 7.9 & 0.03 \\
\hline
\end{tabular}

Per-segment analysis. The results for coronary vessels are determined on a per-vessel basis. Values in parentheses represent upper and lower bound for 955 confidence interval. FN - false negatives, FP-false positives, $L R+-$ positive likelihood ratio, $L R--$ negative likelihood ratio, NPV - negative predictive value, $P P V$ - positive predictive value, $T N$ - true negatives, $T P$ - true positives
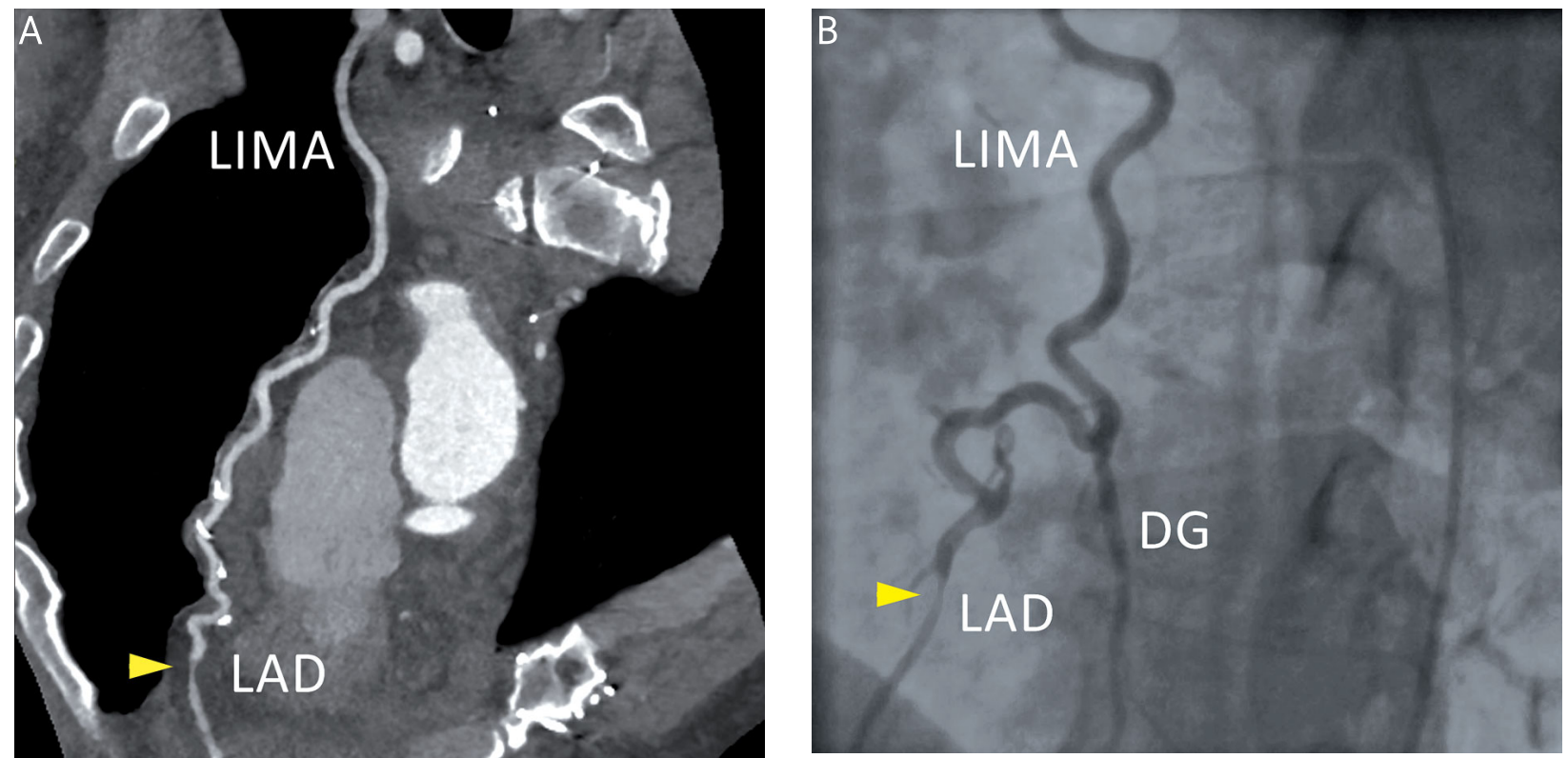

Fig. 3. Curved multiplanar reconstruction demonstrates patent left internal mammary artery graft with significant stenosis (yellow arrowhead) in the distal runoff segment of the left anterior descending coronary artery below the anastomotic site (A). Corresponding invasive coronary angiography confirms patent and non-stenotic left internal mammary artery graft to the left anterior descending coronary artery and the diagonal branch with tight stenosis (yellow arrowhead) in the distal segment of the left anterior descending coronary artery (B) $D G$ - diagonal branch, LAD - left anterior descending coronary artery, LIMA - left internal mammary artery graft

Ryc. 3. Badanie metodą tomografii komputerowej. Rekonstrukcja wielopłaszczyznowa pokazująca istotne zwężenie $w$ dystalnym segmencie gatęzi przedniej zstępującej, poniżej miejsca zespolenia z pomostem tętniczym (lewa tętnica piersiowa wewnętrzna, żółta strzatka) (A). Obraz koronarografii inwazyjnej przedstawiający niezwężony pomost tętniczy oraz zwężenie $w$ dystalnym segmencie tętnicy natywnej, poniżej zespolenia (B)

$D G$ - gałąź diagonalna, LAD - gałąź przednia zstępująca lewej tętnicy wieńcowej, LIMA - lewa tętnica piersiowa wewnętrzna

with at least 1 significant graft stenosis on ICA were correctly classified by DS-CCTA, whereas in 33 of 36 (92\%) patients the presence of significant graft disease was correctly ruled out. Thus, the diagnostic accuracy of DS-CCTA for the detection of patients with at least 1 significant graft stenosis was $96 \%$ (86/90). The DS-CCTA also showed good diagnostic accuracy $(96 \%, 86 / 90)$ for the detection of patients with at least 1 significant lesion in the combination of bypass grafts, non-grafted coronary arteries, and distal runoff segments. Overall, all bypass grafts were clas- 
Table 3. Effect of coronary calcium load on the diagnostic accuracy of DS-CCTA in a segment-based analysis Tabela 3. Wpływ liczby zwapnień w tętnicach wieńcowych na przydatność diagnostyczna tomografii komputerowej, analiza segmentów

\begin{tabular}{|c|c|c|c|c|c|c|c|c|c|c|c|c|}
\hline & $\begin{array}{c}\text { Prevalence } \\
\text { of disease [\%] }\end{array}$ & $N$ & TP & $\mathrm{TN}$ & FP & $\mathrm{FN}$ & $\begin{array}{c}\text { Sensivity } \\
\text { [\%] }\end{array}$ & $\begin{array}{l}\text { Specificity } \\
{[\%]}\end{array}$ & $\begin{array}{l}\text { PPV } \\
{[\%]}\end{array}$ & $\begin{array}{l}\text { NPV } \\
{[\%]}\end{array}$ & $\mathrm{LR}+$ & LR- \\
\hline \multicolumn{13}{|c|}{ All coronary segments } \\
\hline None & 18 & 388 & 58 & 311 & 7 & 12 & $83(72-90)$ & $98(95-99)$ & $89(78-95)$ & $96(93-98)$ & 37.6 & 0.17 \\
\hline Moderate & 39 & 496 & 179 & 276 & 25 & 16 & $92(87-95)$ & $92(88-94)$ & $88(82-92)$ & $94(91-97)$ & 11 & 0.09 \\
\hline Severe & 57 & 221 & 119 & 69 & 26 & 7 & $94(88-97)$ & $73(62-81)$ & $82(75-88)$ & $91(81-96)$ & 3.4 & 0.08 \\
\hline \multicolumn{13}{|c|}{ Nongrafted and runoffs } \\
\hline None & 10 & 336 & 29 & 298 & 3 & 6 & $83(66-93)$ & $99(97-100)$ & $91(74-97)$ & 98 (95-99) & 83.1 & 0.17 \\
\hline Moderate & 25 & 358 & 79 & 253 & 16 & 10 & $89(80-94)$ & $94(90-96)$ & $83(74-90)$ & $96(93-98)$ & 14.9 & 0.12 \\
\hline Severe & 45 & 93 & 38 & 45 & 6 & 4 & $90(76-97)$ & $88(75-95)$ & $86(72-94)$ & $92(79-97)$ & 7.7 & 0.11 \\
\hline
\end{tabular}

Per-segment analysis

Table 4. Per-patient analysis of DS-CCTA diagnostic accuracy for the detection of significant graft and coronary artery disease

Tabela 4. Przydatność diagnostyczna dwuźródłowej tomografii komputerowej w identyfikacji istotnych zwężeń w pomostach i natywnych tętnicach wiencowych, analiza per-patiet

\begin{tabular}{lcccccccccccc} 
& $\begin{array}{c}\text { Prevalence } \\
\text { of disease [\%] }\end{array}$ & $N$ & TP & TN & FP & FN & $\begin{array}{c}\text { Sensivity } \\
{[\%]}\end{array}$ & $\begin{array}{c}\text { Specificity } \\
{[\%]}\end{array}$ & $\begin{array}{c}\text { PPV } \\
{[\%]}\end{array}$ & $\begin{array}{c}\text { NPV } \\
{[\%]}\end{array}$ & LR+ & LR- \\
\hline Bypass grafts & 60 & 90 & 53 & 33 & 3 & 1 & $98(89-100)$ & $92(76-98)$ & $95(84-99)$ & $97(83-100)$ & 11.8 & 0.02 \\
\hline $\begin{array}{l}\text { Nongrafted } \\
\text { and runoffs }\end{array}$ & 88 & 90 & 76 & 9 & 2 & 3 & $96(88-99)$ & $82(48-97)$ & $97(60-99)$ & $75(43-93)$ & 5.3 & 0.05 \\
\hline $\begin{array}{l}\text { Bypass graft } \\
\text { and nongrafted } \\
\text { and runoffs }\end{array}$ & 93 & 90 & 82 & 4 & 2 & 2 & $98(91-100)$ & $67(24-94)$ & $98(91-100)$ & $67(24-94)$ & 2.9 & 0.04 \\
\end{tabular}

Per-patient analysis

sified as evaluable and 8 of 8 (100\%) unevaluable nongrafted coronary segments were present in patients with significant stenoses. The results are listed in Table 4.

\section{Discussion}

To the best of our knowledge, the present study is the third, but the largest in terms of sample size, to assess the diagnostic accuracy of DS-CCTA in the evaluation of significant graft and coronary artery disease in symptomatic patients after CABG $[15,16]$. Our findings demonstrate that noninvasive DS-CCTA has high diagnostic accuracy to rule out significant stenosis in bypass grafts, whereas ICA is still required for assessment of obstructive coronary artery disease after CABG.

Sixty-four multidetector $\mathrm{CT}$ technology reported sensitivities between $85 \%$ and $100 \%$ with specificities between $89 \%$ and $97 \%$ for the detection of significant graft disease in symptomatic post-CABG patients [5-12]. In addition, almost all studies showed satisfactory graft assessability (83-100\%) with exclusion of a limited number of examinations because of metal clips, calcification and/or motion artefacts. The introduction of the DS-CCTA scanner equipped with 2 tube-detector systems allows acqui- sition of images during a shorter time window (83 ms) with a potential for less coronary motion compared to previous generation 64-detector CCTA [14]. In addition, fast scanning of the whole thorax can be performed during short breath holds (10 s to $15 \mathrm{~s}$ ), which is important in the assessment of arterial grafts. Indeed, in our study, DSCCTA demonstrated a sensitivity of $99 \%$ and specificity of $96 \%$ for the assessment of significant graft disease, and compares favourably with the reported diagnostic accuracy of 64-detector CCTA. In addition, we showed excellent graft assessability (100\%) without exclusion of any examinations because of image quality by using DS-CCTA. We believe that this may be attributed to higher temporal resolution resulting in fewer motion and metal artefacts within the vicinity of the graft. However, similar to previous studies using 64-detector CCTA [19], misclassification of totally occluded grafts as significant stenoses occurred in 2 cases, resulting in a reduced negative predictive value for the detection of graft occlusion in our study. Although the clinical implications of these phenomenon are minimal (because both the presence of graft stenosis or occlusion on CCTA would lead to ICA), the usefulness of DS-CCTA to reliably confirm graft occlusion is still unsatisfactory and may be mainly caused by limitations in dif- 
ferentiating between retrograde and antegrade bypass flow in case of functional graft occlusion [8].

For complete evaluation of symptomatic post-CABG patients, both the native coronary circulation and bypass grafts need to be assessed. Most publications on the diagnostic accuracy of 64-detector CCTA have reported sensitivities between $80 \%$ and $93 \%$ with specificities between $76 \%$ and $90 \%$ for the detection of significant coronary artery disease $[6,7,9,10,12]$. Moreover, sensitivities between $86 \%$ and $96 \%$ with specificities between $86 \%$ and $94 \%$ for assessment of significant lesions in non-grafted coronary arteries and distal runoffs were demonstrated. Importantly, up to $25 \%$ of coronary segments were found non-evaluable with 64-detector CT scanners, and misclassification of stenosis frequently occurred. The present report is the largest, in terms of sample size, to assess the diagnostic accuracy of CCTA in the detection of obstructive disease in native coronary arteries after CABG. Overall, sensitivity for the assessment of all native coronary arteries on a per-segment basis was $91 \%$ with specificity of $92 \%$, and the negative predictive value of $95 \%$. Significantly, DS-CCTA showed even higher negative predictive value (99\%) for the diagnosis of significant runoff disease. Furthermore, it is noteworthy that we excluded only $2 \%$ of all coronary segments due to significant image artefacts. On the other hand, sensitivity and specificity for the identification of significant stenoses in non-grafted and distal runoff segments taken together were still unsatisfactory and averaged $88 \%$ and $96 \%$, respectively. In addition, we demonstrated a significant impairment of accuracy in the presence of high calcium load representing the main contributor of stenosis overestimation and falsepositive findings. In conclusion, while our results slightly exceed the reported diagnostic accuracy of 64-detector CCTA, the DS-CCTA assessment of native coronary circulation after CABG is still challenging and may be clinically useful in certain patient populations (lack of severe calcification, low and regular heart rate, low body mass index).

To the best of our knowledge, the present report is the second study, after our preliminary results [16], to assess the diagnostic accuracy of DS-CCTA in symptomatic patients after CABG. In the study of Weustink et al. the diagnostic accuracy of $100 \%$ for the assessment of significant graft disease was reported [15]. In addition, the authors obtained per-segment sensitivities of $97 \%$ and $95 \%$ with specificities of $92 \%$ and $100 \%$ for the detection of significant coronary artery disease in non-grafted and runoff vessels, respectively. While these values somewhat exceed the diagnostic accuracy reported in our study, we did exclude significantly fewer coronary segments (22\% vs. 38\%) located distally to a total occlusion and with a lumen diameter $<1.5 \mathrm{~mm}$, and analyzed all coronary arteries and/or grafts with stents. Furthermore, the lower prevalence of patients with at least 1 coronary and/or bypass graft stenosis in our study reflects the pre-test probability in a population with lower prevalence of disease and does not potentially lead to an overestimation of the positive predictive value in the per-patient analyses. Finally, by performing over 3,000 CCTA studies per year in a high-volume cardiac centre, and contrary to the study of Weustink et al., we are truly sceptical about omitting beta-blocker administration immediately before the CCTA scan, especially in such a challenging population as postCABG patients. Thus, in our opinion, the present report represents the real-life diagnostic performance of DC-CCTA in consecutive patients after CABG.

Provided that CCTA is to obviate the need for ICA in prior CABG patients, it should provide accurate information both about the bypass grafts and non-grafted coronary vessels. According to the American College of Cardiology Foundation Appropriateness Criteria based on 16- and 64-detector CCTA studies, the routine use of CCTA has been classified as an appropriate indication for evaluation of graft patency in symptomatic patients after CABG [13]. Significantly, assessment of the asymptomatic post-CABG population has been considered as an uncertain or inappropriate indication mainly due to unsatisfactory accuracy in the detection of significant coronary artery disease by CCTA. In our opinion, although the reported diagnostic performance of DS-CCTA seems to exceed the accuracy achieved in 64-detector CCTA studies, the DSCCTA assessment of native coronary circulation after CABG is still challenging and should be considered as a complementary rather than surrogate diagnostic test to ICA.

There are some limitations that have to be taken into account when interpreting our data. First, the reported study was a single centre experience. Second, since our population consisted of symptomatic patients scheduled for ICA long after CABG, the diagnostic accuracy might be biased in a lower-risk population without symptoms. However, the reported likelihood ratios are independent of disease prevalence per se and should be applicable to other clinical scenarios. Finally, the potential relation between arrhythmia, the presence of stents or body mass index, and CCTA false results was not assessed.

\section{References}

1. Cameron AA, Davis KB, Rogers WJ. Recurrence of angina after coronary artery bypass surgery: predictors and prognosis (CASS Registry). Coronary Artery Surgery Study. J Am Coll Cardiol 1995; 26: 895-899.

2. Alderman EL, Kip KE, Whitlow PL, et al. Native coronary disease progression exceeds failed revascularization as cause of angina after five years in the Bypass Angioplasty Revascularization Investigation (BARI). J Am Coll Cardiol 2004; 44: 766-774.

3. Clark AL, Brennan AG, Robertson LJ, McArthur JD. Factors affecting patient radiation exposure during routine coronary angiography in a tertiary referral centre. $\mathrm{Br} J$ Radiol 2000; 73: 184-189.

4. Mark DB, Berman DS, Budoff MJ, et al. ACCF/ACR/AHA/NASCI/ SAIP/SCAI/SCCT 2010 expert consensus document on coronary computed tomographic angiography: a report of the American 
College of Cardiology Foundation Task Force on Expert Consensus Documents. J Am Coll Cardiol 2010; 55: 2663-2699.

5. Pache G, Saueressig U, Frydrychowicz A, et al. Initial experience with 64-slice cardiac CT: non-invasive visualization of coronary artery bypass grafts. Eur Heart J 2006; 27: 976-980.

6. Ropers D, Pohle FK, Kuettner A, et al. Diagnostic accuracy of noninvasive coronary angiography in patients after bypass surgery using 64-slice spiral computed tomography with 330-ms gantry rotation. Circulation 2006; 114: 2334-2341.

7. Malagutti P, Nieman K, Meijboom WB, et al. Use of 64-slice CT in symptomatic patients after coronary bypass surgery: evaluation of grafts and coronary arteries. Eur Heart J 2007; 28: 1879-1885.

8. Jabara R, Chronos N, Klein L, et al. Comparison of multidetector 64-slice computed tomographic angiography to coronary angiography to assess the patency of coronary artery bypass grafts. Am J Cardiol 2007; 99: 1529-1534.

9. Dikkers R, Willems TP, Tio RA, et al. The benefit of 64-MDCT prior to invasive coronary angiography in symptomatic post-CABG patients. Int J Cardiovasc Imaging 2007; 23: 369-377.

10. Onuma Y, Tanabe K, Chihara R, et al. Evaluation of coronary artery bypass grafts and native coronary arteries using 64-slice multidetector computed tomography. Am Heart J 2007; 154: 519-526.

11. Meyer TS, Martinoff S, Hadamitzky M, et al. Improved noninvasive assessment of coronary artery bypass grafts with 64-slice computed tomographic angiography in an unselected patient population. J Am Coll Cardiol 2007; 49: 946-950.

12. Nazeri I, Shahabi P, Tehrai M, et al. Assessment of patients after coronary artery bypass grafting using 64-slice computed tomography. Am J Cardiol 2009; 103: 667-673.

13. Taylor AJ, Cerqueira M, Hodgson JM, et al. ACCF/SCCT/ACR/AHA/ ASE/ASNC/NASCI/SCAI/SCMR 2010 appropriate use criteria for cardiac computed tomography. A report of the American College of Cardiology Foundation Appropriate Use Criteria Task Force, the Society of Cardiovascular Computed Tomography, the American College of Radiology, the American Heart Association, the American Society of Echocardiography, the American Society of Nuclear Cardiology, the North American Society for Cardiovascular Imaging, the Society for Cardiovascular Angiography and Interventions, and the Society for Cardiovascular Magnetic Resonance. J Am Coll Cardiol 2010; 56: 1864-1894.

14. Achenbach S, Ropers D, Kuettner A, et al. Contrast-enhanced coronary artery visualization by dual-source computed tomography: initial experience. Eur J Radiol 2006; 57: 331-335.

15. Weustink AC, Nieman K, Pugliese F, et al. Diagnostic accuracy of computed tomography angiography in patients after bypass grafting: comparison with invasive coronary angiography. JACC Cardiovasc Imaging 2009; 2: 816-824.

16. Kepka C, Opolski MP, Kruk M, et al. Dual-source computed tomography angiography in patients after bypass grafting: comparison with invasive coronary angiography. Postep Kardiol Inter 2010; 6: 12-20.

17. Bongartz G, Golding SJ, Jurik AG. 2004 CT quality criteria, European Commission. Available at: http://www.msct.info/CT_Quality Criteria.htm. Accessed April 20, 2008.

18. Austen WG, Edwards JE, Frye RL, et al. A reporting system on patients evaluated for coronary artery disease: report of the Ad Hoc Committee for Grading of Coronary Artery Disease, Council of Cardiovascular Surgery, American Heart Association. Circulation 1975; 51 (Suppl): 5-40.
19. Stein PD, Yaekoub AY, Matta F, Sostman HD. 64-slice CT for diagnosis of coronary artery disease: a systematic review. Am J Med 2008; 121: 715-725. 